\title{
Dr. Robert Bauer (1950-2014) in memoriam: botanist, mycologist, and electron microscopist
}

\author{
Franz Oberwinkler ${ }^{1}$
}

Received: 17 August 2015 / Accepted: 21 September 2015 /Published online: 13 October 2015

(C) German Mycological Society and Springer-Verlag Berlin Heidelberg 2015

Unexpectedly and tragically, Robert Bauer died September 7, 2014. He was born March 20, 1950 in Großbettlingen, BadenWürttemberg. After qualification as a metal craftsman, he decided to study biology at the University of Tübingen, where he obtained a diploma for his study "Sporenbildung bei Coleosporium tussilaginis (Pers.) Lév." in 1980. He continued an experimental approach to elucidate ontogenetic and karyological features in rust fungi and finished his dissertation "Experimentell-ontogenetische und karyologische Untersuchungen an Uredinales" in 1983. Expanding such studies in related groups, Bauer became more and more interested in smuts, developed special skills for transmission electron microscopy, and successfully combined culture work on fungi with newly available techniques and organisms.

This reappraisal of Bauer's contributions to mycology is arranged systematically and partly chronologically and includes exclusively his publications as author or coauthor. A list of these scientific publications concludes this tribute to him with the intention to unroll a scientist's life dedicated to fungi and their hosts.

\section{Pucciniomycotina, rust fungi, and related taxa}

The nomenclature for the subdivision Pucciniomycotina of Basidiomycota was introduced by Bauer et al. (2006). It included a systematic and phylogenetic rearrangement of taxa

Section Editor: Dominik Begerow

Franz Oberwinkler

franz.oberwinkler@uni-tuebingen.de

1 Universität Tübingen, Tübingen, Germany down to ordinal level (Fig. 1). It is a comprehensive overview that since then is called "simple-septate basidiomycetes" and was adopted by later studies of Aime et al. (2006) and Hibbett et al. (2007), of which Bauer was coauthor.

Cryptomycocolax abnormis was described by Oberwinkler and Bauer (1990) from material collected on the volcano Irazú, Costa Rica, in which the species parasitizes an ascomycete through two types of colacosomes. One of these colacosomes was described by Oberwinkler et al. (1990a) and Bauer and Oberwinkler (1991) from Platygloea peniophorae. The simple-pored septa of $C$. abnormis are associated with Woronin body-like structures, a characteristic, found in basidiomycetes only in one additional species, Colacosiphon filiformis (Kirschner et al. 2001). The interphase of nuclear division shows spindle pole bodies (SPBs) whose position, structure, and duplication are similar to those of ascomycetes. In late interphase, SPB middle pieces as in basidiomycetes are developed. These subcellular organelles support the interpretation that Cryptomycocolacomycetes range in a basal position of basidiomycetous phylogeny, a view supported by molecularly based hypotheses (Bauer et al. 2006). The apparently convergent occurrence of the colacosomes, unique mycoparasitic cell organelles in Cryptomycocolacomycetes and Microbotryomycetes was discussed by Bauer et al. (2006).

Several collections of Mixia osmundae from Japan were kindly provided by Junta Sugiyama for electronmicroscopic studies. Unfortunately, unambiguous stages of nuclear divisions in the Mixia sporangium could not be detected. Thus, it remained unsolved whether Mixia propagules are meiospores or conidia. However, subcellular characteristics of cell walls and SPBs indicate a basal position of M. osmundae in Basidiomycota, an interpetation supported by molecular data (Weiß et al. 2004a, Aime et al. 2006, Bauer et al. 2006). The order Mixiales and the class Mixiomycetes were introduced by Bauer et al. (2006). 
Fig. 1 Simplified phylogeny of Pucciniomycotina. The ordinal phylogeny and the listed genera are intended to serve as a guideline for the accompanying text. The genus Bauerago, dedicated to Robert Bauer, is a member of the Microbotryales

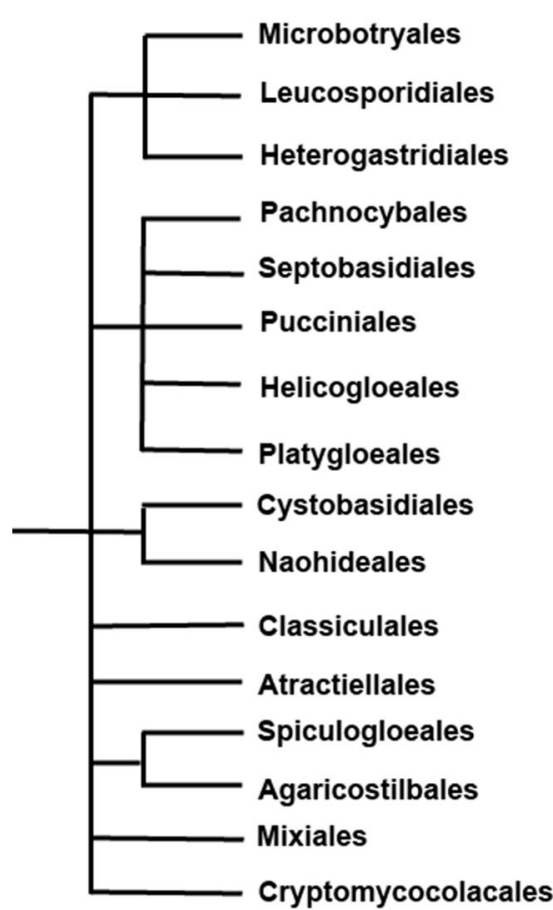

Microbotryum, Liroa, Sphacelotheca, Aurantiosporium, Bauerago, Fulvisporium, Ustilentyloma, Zundeliomyces, Kriegeria

Leucosporidium, Leucosporidiella

Heterogastridium, Colacogloea, Atractocolax

Pachnocybe

Septobasidium

Coleosporium, Cronartium, Gymnosporangium, Hyalopsora, Milesia Ochropsora, Stomatisora, Tranzschelia, Uredinopsis

Helicobasidium, Tuberculina

Herpobasidium, Platygloea

Cystobasidium, Occultifur

Naohidea

Classicula, Jaculispora

Atractiella, Helicogloea, Phleogena

Spiculogloea

Agaricostilbum, Chionosphaera, Kurtzmanomyces

Mixia
Ontogenetic studies in phragmobasidia of Agaricostilbum pulcherrimum, Gymnosporangium clavariiforme, Helicogloea lagerheimii, Phleogena faginea, Platygloea peniophorae, and Sphacelotheca polygoni-persicariae (Bauer and Oberwinkler 1986a) under different experimental conditions led to the conclusion that external factors, such as air, water, and water agar, strongly influence germination patterns. They can induce the formation of ballistospores, microconidia, or yeast cells. Also, hyphae with terminal appressoria can be formed. The authors concluded that with the formation of basidial cells, the meiosporangial ontogeny is terminated. Meiosis and its SPB cycle of $A$. pulcherrimum were studied with a transmission electron microscope (Bauer et al. 1992). Together with Spiculogloeales, the Agaricostilbales were placed in the Agaricostilbomycetes (Bauer et al. 2006). A new anamorphic yeast, Kurtzmanomyces insolitus, was described by Sampaio et al. (1999b). Molecular studies (Weiß et al. 2004, Aime et al. 2006, Bauer et al. 2006, Bauer et al. 2009) confirmed a basal position of Agaricostilbomycetes within the Pucciniomycotina. Members of Spiculogloeales (Bauer et al. 2006) are mycoparasites with tremelloid haustoria.

In a revision of the gasteroid, auricularioid heterobasidiomycetes, Oberwinkler and Bauer (1989) studied basidiocarps, hyphae, cell organelles, basidia, basidiospores, yeasts, and conidia. They also considered the available data of 5S RNAs and recognized complex subcellular structures such as symplechosomes, apparently synapomorphic for members of the Atractiellales. As a taxonomical consequence for stilboid, gasteroid taxa they proposed Agaricostilbales, Agaricostilbaceae, Pachnocybaceae, and Atractogloeaceae.
Later, two pycnidial atractielloid basidiomycetes, the teleomorph Basidiopycnis hyalina and the anamorph Proceropycnis pinicola, were described (Oberwinkler et al. 2006). Still enigmatic is the report of atractielloid fungi as mycosymbionts in epiphytic neotropical orchids (Kottke et al. 2010).

The teleomorphic genus Classicula and the anamorphic Jaculispora were included in the Classiculales (Bauer et al. 2003), later raised to Classiculomycetes (Bauer et al. 2006). Classicula fluitans is the basidial stage of Naiadella fluitans. They are mycoparasites with tremelloid haustoria. In Naohidea sebacea, Bauer (2004) detected nanometer pores in the intracellular haustoria of this mycoparasite, and Weiß et al. (2004) supported the phylogenetic position of the Naohideales in the Cystobasidiomycetes by molecular data.

Occultifur internus, a mycoparasite growing in the basidiocarps of Dacrymycetes species, has tremelloid haustoria with nanometer pores and septal pores with cystosomes (Bauer 2004). Sampaio et al. (1999a) found Occultifur externus, developing basidial stages under laboratory conditions, and the affiliation to Cystobasidiales could be proven.

Meiosis, spindle pole cycle, and septal pores of Herpobasidium filicinum, Platygloeales were studied transmission electron microscopically by Bauer and Oberwinkler (1994).

Spectacular results were derived from intensive studies in Tuberculina spp., Helicobasidiales, turning out to be anamorphs of Helicobasidium (Lutz et al. 2004a), and mycoparasites of the comparatively closely related rust fungi. The identity of Tuberculina spp. and Helicobasidium spp. was 
proven experimentally (Lutz et al. 2004b). Bauer et al. (2004) studied Tuberculina persicina parasitizing Puccinia silvatica and Tranzschelia pruni-spinosae. They found micrometer fusion channels between parasite and host cells, apparently allowing transfer of cell organelles. Experiments to elucidate host specificities revealed a high diversity of the mycoparasites (Lutz et al. 2004c). Two reports about "The double life of a fungus" were published by the German Research Council, DFG (Lutz et al. 2006, 2007).

The ontogeny of basidia and nuclear changes in Pucciniales were studied by Bauer $(1983,1986,1987)$ in experimental approaches. Axenic cultures of Coleosporium (Deml et al. 1982a, b) later turned out to be yeast contaminations. Bauer found that secondary spore formation depends on the monokaryotic stage. Nuclear degeneration during ballistospore production was investigated in Cronartium asclepiadeum (Bauer and Oberwinkler 1988). The unusual case of gasteroid basidia in Ochropsora ariae was studied in vivo and in vitro (Bauer and Oberwinkler 1986b), and the ultrastructure of the host-parasite interface in the fern rusts Milesia, Uredinopsis, and Hyalopsora was analysed (Berndt et al. 1994). The morphology and phylogenetics of Stomatisora, including Stomatisora psychotriicola sp. nov., were investigated by Wood et al. (2014).

Comprehensive transmission electron microscopic studies resulted in data that allowed reconstructing meiosis and SPB cycle in Pachnocybe ferruginea (Bauer and Oberwinkler 1990c), a species that was raised in taxonomic ranks to Pachnocybaceae (Oberwinkler and Bauer 1989) and Pachnocybales (Bauer et al. 2006).

The detection of auricularioid basidia with sessile, tetraradiate basidiospores in the pycnidioid Hyalopycnis blepharistoma led to the introduction of Heterogastridium pycnidioideum (Oberwinkler et al. 1990b). All members of the Heterogastridiales are mycoparasites and possess colacosomes (Bauer 2004), as described by Oberwinkler et al. (1990a) and Bauer and Oberwinkler (1991) from Platygloea peniophorae, then named Colacogloea peniophorae. A second species, C. bispora, parasitizing Tubulicrinis sp., with collections from Denmark and Taiwan, was described by Oberwinkler et al. (1999). A new species, vectored by bark beetles on conifers was isolated, cultivated, and described in a new genus, Atractocolax pulvinatus (Kirschner et al. 1999).

On the basis of nutritional, ultrastructural, and molecular data, Sampaio et al. (2003) proposed the new orders Leucosporidiales and Sporidiobolales, the new genus Leucosporidiella and the new species Leucosporidium golubevii.

A smut collected in Madeira on Polygonum persicaria was described as the new species Sphacelotheca polygonipersicariae (Deml et al. 1985) and considered to be related to those of the genus Microbotryum because of their obvious similarities. - In a comparative ultrastructural study of Sphacelotheca polygoni-serrulati and Ustilago spp., Bauer et al. (1989) realised that hyphal septa of these false and true smuts differ markedly. In Ustilago, the septal ingrowth stops, leaving a central pore, while in S. polygoni-serrulati, septal pores could not be found. Meiosis and SPB cycle of this species were studied by Bauer et al. (1991), and that of Microbotryum violaceum by Berbee et al. (1990), and compared with the corresponding features of Ustilago maydis and Sphacelotheca polygoni-serrulati. Analysing cell wall carbohydrates, Prillinger et al. (1993) succeeded in separating Ustilago s. str., Sporisorium, Entyloma, and Melanotaenium from Microbotryum and Sphacelotheca, later transferred to their own order, Microbotryales (Bauer et al. 1997). The genus Bauerago, introduced for Ustilago species parasitizing Cyperus, Juncus, and Luzula hosts, could be verified subsequently by molecular analyses (Bauer et al. 2006). Also, Fulvisporium is a genus in the Microbotryales (Vánky et al.1997). A well illustrated life cycle of Microbotryum lychnidis-dioicae on Silene latifolia was published by Schäfer et al. (2010).

The unique basidiomycetous parasite Kriegeria eriophori, only found in scattered regions and occurring in aerenchymas of Scirpus, was studied intensively light and electron microscopically as well as molecularly (Bauer et al. 2006). Multipored hyphal septa were detected, unique at that time for Basidiomycota, but later also found in Bartheletia paradoxa (see below).

\section{Ustilaginomycotina, true smut fungi}

In the context of our research preferences, smut fungi became the main objects of Robert Bauer, to be studied with a transmission electron microscope intensively and comprehensively since the end of the 1980s. In addition, it is important to mention here that many controversial discussions were going on in our teaching and lab programmes about host dependencies of specialised parasitic fungi in general, but with a main focus on rusts and smuts. It was already well understood that Pucciniales passed through a close coevolutionary history with their host plants. In contrast, Ustilaginales were generally assumed to lack such traits, and species-rich genera with broadly spreading host ranges, like Urocystis and Ustilago, was considered convincing evidence. However, when it became clear that, for example, Exobasidium and Graphiola belong to the smut relationship, and the heterogeneity of Ustilago was elucidated step by step in our group, the attitude switched completely. Very quickly, smuts underwent a remarkable series of taxonomic reappraisals.

For the convenience of the reader, the phylogeny within the class (Fig. 2), as published by Bauer et al. (1997), is used here as guideline for the following text. The morphological and ultrastructural characters studied before, and interpreted 


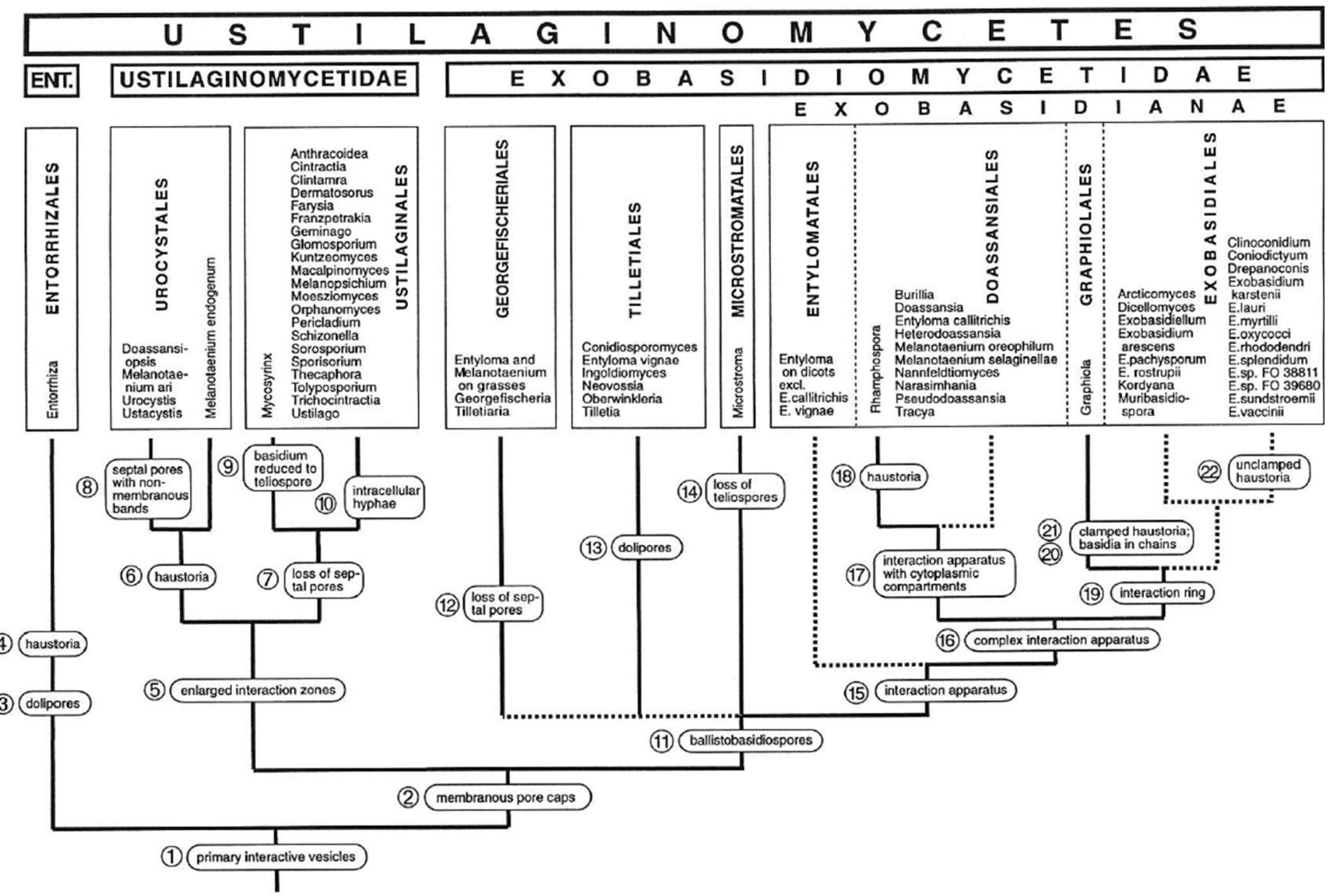

Fig. 2 Systematic arrangement and phylogeny of the Ustilaginomycetes as proposed by Bauer et al. (1997). (1) Interaction with primary interactive vesicles - without such vesicles. (2) Membranous pore caps or bands - without these structures. (3) Dolipores - simple pores. (4) Haustoria - intercellular hyphae. (5) Enlarged interaction zones - local interaction zones. (6) Haustoria - intercellular hyphae. (7) Loss of septal pores - simple pores. (8) Septal pores with membranous bands - without membranous bands. (9) Basidia reduced to teliospores - teliospores are probasidia. (10) Intracellular hyphae - intercellular hyphae. (11) Ballistosporic basidiospores - repeated loss of ballisto-basidiospores.

comparatively, were applied in a cladistic approach to propose a new systematic arrangement with the intention of a phylogenetic concept. After step by step approval of this phylogeny through newly coming up molecular hypotheses (Begerow et al. 1997, Bauer et al. 1998, Begerow et al. 2006), the class was taxonomically raised to subdivisional level (Bauer et al. 2006). Because there were no justifying data to exclude smuts, such as "Ustomycota", from Basidiomycota, Bauer and Oberwinkler (1997) rejected this proposal rigorously. The new data on smuts accumulated since then were summarised by Bauer et al. (2001a) and accepted in following generalizing treatments (Hibbett et al. 2007). Teliospore development, ultrastructure, liberation, and dispersal in Ustilaginales and Tilletiales as well as in Microbotryum, were studied in 120 species of 37 genera by Piepenbring et al. (1998a-c). The cellular and subcellular ustilaginomycete-host interactions were outlined by Bauer and Oberwinkler (2004). Based on
(12) Loss of septal pores - simple pores. (13) Dolipores - simple pores. (14) Loss of teliospores - teliospores. (15) Interaction apparatus primary interactive vesicles. (16) Complex interaction apparatus simple interaction ring. (17) Interaction apparatus with cytoplasmic compartments - without cytoplasmic compartments. (18) Haustoria intercellular hyphae. (19) Interaction ring - without interaction ring. (20) Basidia in chains - not in chains. (21) Clamped haustoria intercellular hyphae. (22) Unclamped haustoria - intercellular hyphae. The text follows the scheme from left to right

sequence data, yeasts of smuts could be integrated in the new phylogenetic system of Begerow et al. (2000). Bauer contributed also to assembling the fungal tree of life (Celio et al. 2006).

Traditionally, Entorrhiza species, parasitizing root cells of Cyperaceae and Juncaceae, were classified as smuts (Fig. 2). They were studied in our institute intensively. When maturing, the intracellulary grown smut spores are internally divided into four cells, each of them producing a germination hypha (Bauer et al. 2001a). Using ultrastructural and molecular data, Bauer et al. (1997) and Begerow et al. (1997) classified the Entorrhizales as sister to the remaining smuts. Entorrhizaceae and Entorrhizales were described by Bauer and Oberwinkler (in Bauer et al. 1997). Vánky et al. (2007) transferred the South African Entorrhiza calospora, growing in roots of diverse species of Aizoaceae, Molluginaceae, and Portulacaceae, and also producing galls in the newly proposed 
genus Talbotiomyces. Because of lacking ontognetic, ultrastructural, and molecular data, a proper systematic treatment was impossible, but recently available sequences indicate the relationship with Entorrhiza (Riess et al. 2015). Simultaneously, the results of a five-gene phylogeny were taken for granted to propose the Entorrhizomycota, and to suggest that the teliospore tetrads of Entorrhiza represent the prototype of the dikaryan meiosporangium (Bauer et al. 2015).

In the new phylogenetic system of smut fungi (Bauer et al. 1997), Bauer and Oberwinkler proposed the Urocystales and the Mycosyringaceae. Bauer et al. (1995a) studied the cellular interaction of Ustacystis waldsteiniae and also investigated its septal pores (Bauer et al. 1995b). For Mycosyrinx nonveilleri, Vánky and Bauer (in Vánky 1996, not cited) introduced the new genus Geminago. Unusual basidial ontogenies in the Costa Rican smuts Doassansiopsis limnocharidis, Mycosyrinx cissi, and Thecaphora haumani were found by Piepenbring and Bauer (1995). Melanotaenium indicum, parasitizing Ischaemum indicum was transferred into the new genus Phragmotaenium by Bauer et al. (2001b). The marine Ruppia maritima can be infected by a smut, originally described as Melanotaenium ruppiae, but recognized as a separate genus, Flamingomyces, by Bauer et al. (2007). Another new genus, Antherospora, was proposed for the anther smut in Muscari and Scilla species, Ustilago vaillantii (Bauer et al. 2008b). The new family, Floromycetaceae, was introduced to accomodate this genus and Floromyces anemarrhenae (Thecaphora a.), growing in Anemarrhena asphodeloides, Agavaceae, (Vánky et al. 2008b). A revision of Thecaphora (Glomosporiaceae) showed that Glomosporium, Kochmania and Tothiella had to be synonymized with Thecaphora (Vánky et al. 2008a). For Melanotaenium oxalidis, known from the North American Oxalis oregana, a new genus, Melanoxa, was erected (Lutz et al. 2011).

Ustilaginales Ustilago esculenta causes hypertrophy in its host Zizania latifolia and produces edible tissues, highly esteemed in East Asia. Smut spore germination, SPBs, septal pores, and ultrastructural features of host interaction were studied by Nagler et al. (1990). They recognized the natural relationship with Ustilago s. str. and concluded that its own genus, Yenia, is justified. Bauer et al. (1999a) analysed morphological and ultrastructural characters of Ustilago osmundae on Osmunda regalis and $O$. cinnamomea. They recognized high structural conformity with the Melanotaeniaceae. Consequently, the smut on the royal fern was transferred into its own genus, Exoteliospora, and Ustilago marina, growing on the marine Eleocharis parvula, also deserved to be excluded from Ustilago, and was, therefore, generically renamed as Parvulago by Bauer et al. (2007). The female flowers of Carex and of other cyperaceous plants infected by Anthracoidea species, were long lasting objects of intensive collecting and studies in our group (Hendrichs et al. 2005), which required also partial re-investigations of the main host itself (Hendrichs et al. 2004). Prillinger et al. (2009) reported the new Schizonella caricis-atratae, growing on Carex atrata in Austria. In a predominantly molecularly based phylogenetic approach of the Ustilaginomycotina, Begerow et al. (2006) confirmed the Anthracoideaceae, Ustilaginaceae, and Websdaneaceae, but rejected the Cintractiaceae, Dermatosoraceae, Melanopsichiaceae, and Farysiaceae.

Georgefischeriales Ultrastructural features of species in this order are local interaction zones between parasite and host and the lack of septal pores (Bauer et al. 1997). Additionally, newly available sequence data confirmed the taxon (Begerow et al. 1997). An enlarged sampling enabled Bauer et al. (2001b) to discriminate three families, Eballistraceae, Georgefischeriaceae, and Tilletiariaceae. Eballistra and Phragmotaenium were proposed as new genera. A restudy of Entyloma ossifragi on Narthecium ossifragum (Bauer et al. 2005) provided evidence to include this smut in the Georgefischeriales. The new genus Gjaerumia and the new family Gjaerumiaceae were based on this species.

Tilletiales, bunts Vánky and Bauer (1992) introduced the new genus Conidiosporomyces, characterized by Y-shaped conidia in the smut spore layers. A smut occurring on the grass Ortachne (Muhlenbergia) erectifolia in the Cordillera de Mérida, Venezuela, was described by Vánky and Bauer (1995) as Oberwinkleria anulata. In this species, smut spores are the meiosporangia themselves, and consequently germinate with basidiospores. For Tilletia hyalospora, growing on Nassella and Stipa species, Vánky and Bauer (1996) proposed the genus Ingoldiomyces, which produces ballisto-conidia and ballisto-basidiospores. Black spots on Phaseolus leaves are caused by fungi known previously as Entyloma vignae or Protomycopsis patelii. Piepenbring and Bauer (1997) realised that both names cover the same parasite, which was found to be a member of the Tilletiales, and which was renamed as Erratomyces.

Microstromatales Members of this order have gasteroid holobasidia without probasidia, i.e. without smutspores. Local interaction zones between parasites and hosts were recognized as synapomorphies by Bauer et al. (1997) who also introduced the ordinal name. A revision of Muribasidiospora (Begerow et al. 2001, 2002b) resulted in the separation of $M$. triumfetticola from $M$. indica and the introduction of the new genus Volvocisporium. The latter belongs to the Microstromatales, but $M$. indica remains with the Exobasidiales. De Beer et al. (2006) described the Quambalariaceae for anamorphic fungal parasites of 
Eucalyptus and Corymbia and included them in the Microstromatales according to sequence data.

Entylomatales Bauer and Oberwinkler (in Bauer et al. 1997) proposed the Entylomataceae and Entylomatales, characterized as smuts with teliospores, simple hyphal septa, and interaction apparatus with homogeneous contents.

Doassansiales The order was described by Bauer and Oberwinkler (in Bauer et al. 1997), and besides Doassansiaceae, an additional family, Rhamphosporaceae, was introduced. Host parasite interactions were found to depend on subcellular complex structures. Sequence data supported the new classification (Begerow et al. 1997). Doassinga callitrichis is specialised on Callitriche hosts (Vánky et al. 1998). Two smut species were known from Selaginella hosts, Melanotaenium oreophilum and M. selaginellae. A restudy (Bauer et al. 1999b) delivered facts of Doassansiales relationship, and consequently, the new genus Melaniella and the family Melaniellaceae were proposed.

Graphiolales, the palm smuts Until 1982 the taxonomic position of Graphiola was unsettled. However, our own data unambiguously showed basidiomycetous relationship. This was strongly supported by subsequently available interaction structures (Bauer et al. 1997), and sequencing results (Begerow et al. 1997, Bauer et al. 2006). The latter favoured the insertion of Graphiolales in Exobasidiales.

Exobasidiales In addition to the very distinctive meiosporangial characters of incurved basidiospore development, parasite host interaction is an important synapomorphy of the order (Bauer et al. 1997). It was mentioned already with the Microstromatales that only Muribasidiospora indica belongs to the Exobasidiales, but not M. triumfetticola (Begerow et al. 2001). Begerow et al. (2002a, 2014) preferred a broad concept of Exobasidiales, including the Exobasidiaceae, predominantly infecting Ericanae, and the Cryptobasidiaceae preferring Lauraceae, Brachybasidiaceae on Poaceae and Graphiolaceae on palms. The Cryptobasidiaceae of tropical Central and South America with the genera Botryoconis, Clinoconidium, and Drepanoconis were treated by Hendrichs et al. (2003) morphologically and ultrastructurally.

Ceraceosorales Begerow et al. (2006) described the order with species having intracellular hyphae in hosts and local interaction zones. Two sterigmate basidia emerge through stomata. Based on sequence data, Ceraceosorus is closely related to Entyloma.

\section{Agaricomycotina}

To match taxonomy with phylogeny, Bauer et al. (2006) erected the subdivision Agaricomycotina whose members are said to share type B of the 5S RNA secondary structure, and to contain predominantly glucose and xylose in the cell walls.

Bartheletiaceae A most remarkable rediscovery in recent years was Bartheletia paradoxa, inhabiting leaves of Ginkgo biloba (Scheuer et al 2008). As mentioned above, the species has multipored hyphal septa, thus reminiscent of Kriegeria eriophori. However, even the very careful integrative study could not solve its definite phylogenetic position.

The basal class of Agaricomycotina, Tremellomycetes, comprising Tremellales, Filobasidiales, and Cystofilobasidiales (Fig. 3), was recently reviewed by Weiß et al. (2014). A yeast, isolated from Asterophora lycoperdoides, developed a hyphal phase in culture. The septal pores of these hyphae were of the Tremella type (Laaser et al. 1988). The mycoparasitic interaction of Tetragoniomyces uliginosus with Rhizoctonia sp. was studied transmission electron microscopically by Bauer and Oberwinkler (1990a). A direct cytoplasm-cytoplasm connection through a single nanometer pore at the haustorial hyphal tip could be detected. The pore membrane appeared continuous with the plasma membrane of both cells. An intrahymenial mycoparasite, Phragmoxenidium mycophilum, was found in Uthatobasidium fusisporum (Oberwinkler et al. 1990c). Because tremelloid parenthesomes were lacking at the dolipores, the species and the family Phragmoxenidiaceae were assigned to Tremellales only tentatively. The mycoparasitic interactions of Tremella mesenterica, $T$. encephala, and T. mycophaga were analysed by Zugmaier et al. (1994) light and transmission electron microscopically. They found ultrastructural features similar to those in Tetragoniomyces. Also, subcellular characteristics were used by Kwon-Chung et al. (1995) to discriminate between Filobasidiella depauperata and $F$. neoformans. With an integrative approach, Sampaio et al. (2002) characterized two new genera, Bulleribasidium and Papiliotrema, and three new species, Bulleribasidium oberjochense, Papiliotrema bandonii, and Fibulobasidium murrhardtense.

Filobasidiales With the help of culture experiments, Oberwinkler et al. (1984) were successful to elucidate the life history of Christiansenia pallida, a mycoparasite on Phanerochaete cremea. The tremelloid nanometer pore interaction was found again (Bauer and Oberwinkler 1990b).

Cystofilobasidiales Crossing compatible yeast strains of Cryptococcus ferigula resulted in a teleomorph that was described as Cystofilobasidium ferigula by Sampaio et al. 
Fig. 3 Systematic arrangement and part of the phylogeny of Agaricomycotina with a selection of genera discussed from below upwards in the following text. Tree compiled after Scheuer et al. (2008) and Hibbett et al. (2014), and strongly modified

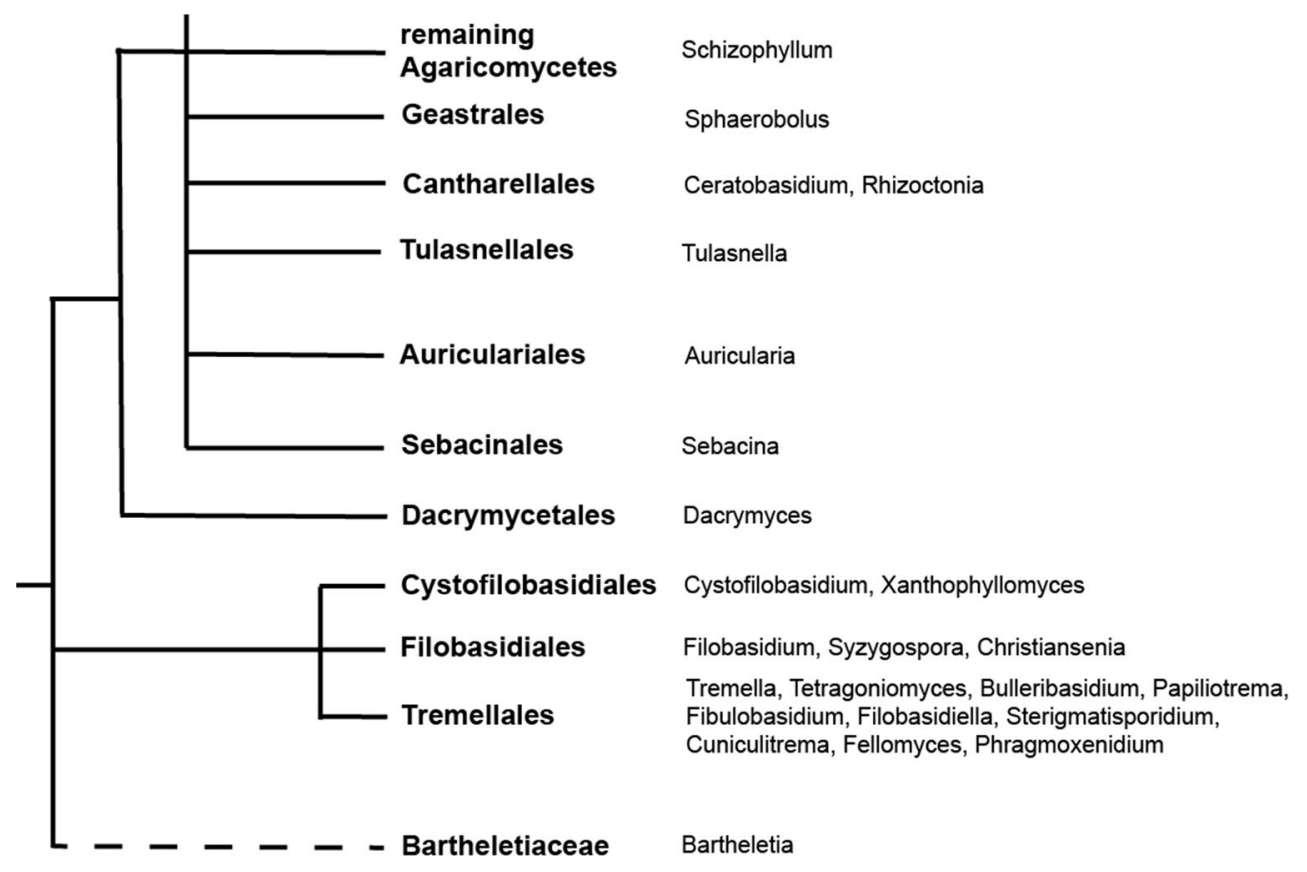

(2001). The genome of the basal agaricomycete Xanthophyllomyces dendrorhous provided insights into the organization of its acetyl-CoA derived pathways (Sharma et al. 2015).

Dacrymycetales The uniform Dacrymyces dolipore with continuous parenthesomes was used for detailed ultrastructural comparison with similar pore types of the Sebacinales, Auriculariales, and Tulasnellales (unpublished).

Sebacinales Sebacina spp., sampled from European Picea abies, Fagus sylvatica, Quercus robur, Carpinus betulus, Tilia sp., and others, were identified molecularly and additionally characterised by dolipores with continuous parenthesomes (Selosse et al. 2002, Urban et al. 2003). Weiß et al. (2011) considered the previously overlooked sebacinalean endophytes of ubiquitous distribution. The phylogenetic diversity and structure of sebacinoid fungi, associated with plant communities along an altitudinal gradient, was analysed by Garnica et al. (2012). The state of knowledge on Sebacinales was summarized by Oberwinkler et al. (2013a). The authors concluded that "it appears to be extremely difficult with the techniques available today to gain a better understanding of this enigmatic diversity". This topic was specifically well investigated at the regional scale in Sebacina epigaea and S. incrustans (Riess et al. 2013). Extensive collections of these species and of additional ones from genera, belonging to former "Sebacinales group A", then named Sebacinaceae s. str., were used to find out whether the high molecular diversity can be verified by micromorphological characteristics (Oberwinkler et al. 2014). Herbaceous plants in agricultural and grassland ecosystems were found to be dominated by Serendipita herbamans sp. nov. (Riess et al. 2014).

Tulasnellales The Aneuraceae with their tulasnelloid mycobionts were considered a model for early steps in fungal symbiosis with terrestrial plants (Krause et al. 2011).

Cantharellales A taxonomic re-evaluation of the Ceratobasidium-Rhizoctonia complex was carried out by Oberwinkler et al. (2013b). A new species, Rhizoctonia butinii, attacking spruce, was described.

Occasionally, and for comparative purposes, Robert Bauer studied septal pores of mushrooms, e.g. in Sphaerobolus of the Geastrales, and Schizophyllum of the Agaricales (Hibbett et al. 2014).

\section{Ascomycota}

In the course of intensive investigations in smuts, Nagler et al. (1989) studied Schroeteria delastrina and S. poeltii and found that their septal pores have Woronin bodies, that SPBs are ascomycetes-like, and that karyogamy and meiosis are lacking in sporulating germination hyphae. These results identified Schroeteria as an ascomycete. - Cymadothea trifolii is a parasite in the leaves of Trifolium repens. In a transmission electron microscopic study of freeze substituted material, Simon et al. (2004) found interaction apparatus with long cisternae in the hyphae. The adjacent host cells are forced to let their plasma membranes invaginate into the parasite cells as bubbles that finally are connected with fungal interaction apparatus via tubular structures. Immunochemical tests provided 
evidence that Cymadothea degrades pectins, but not cellulose and xyloglucan (Simon et al. 2005a). Also, the vegetative lifecycle of the clover pathogen was clarified by Simon et al. (2005b). Mycosphaerella podagrariae, a necrotrophic phytopathogen, produces another special cellular interaction system of electron dense appositions with its host Aegopodium podagraria (Simon et al. 2009). The interaction apparatus of Asteridiella callista, Meliolaceae, growing on Stachytarpheta mutabilis, was electron microscopically analysed by Rodríguez Justavino et al. (2014). They found a cisternal interaction apparatus, surrounded by a membrane in a continuum with the fungal plasma membrane, deposition of material at the host cytoplasmic membrane, an encasement of the infection area, and a final degeneration.

Bauer contributed also to broader studies dealing with the phylogeny and systematics of fungi, with special reference to Ascomycota and Basidiomycota, and their yeasts (Prillinger 1996, 2002).

\section{Concluding remarks}

Robert Bauer's 120 publications were concisely reviewed here to provide an insight in his scientific work. He focused decidedly on ultrastructural features of plant parasites, especially basidiomycetes, and their cellular and subcellular interactions with the hosts. The huge amount of data, accumulated over the years, were a challenge to use them for comparative analyses, with the aime to deduce phylogenetic trends for the fungi involved. The upcoming flood of molecular data did not overshadow his work. In contrast, there was a welcome chance to verify hypotheses that were exclusively based on structural characters.

During the few last years, Robert worked on several manuscripts at the same time. He concentrated on his most important, not yet published results. This task was recognized by the German Research Council, DFG, who supported this attempt that, unfortunately, could not be finished by him.

I met Robert first when he was a student of biology at our university, supervised his diploma and doctoral theses, and accompanied his academic and scientific career over 30 years. He was a vital, reliable, friendly, and at times humorous member of our former mycology group, qualities that had a very positive influence on our many students in biology for a long time.

His colleagues, worldwide, will respectfully perpetuate his memory.

\section{Chronological list of Robert Bauer's publications}

The development of research preferences, availability of new methods, and cooperative constellations can be perceived from this arrangement in a time sequence.

\section{0}

Bauer R (1980) Sporenbildung bei Coleosporium tussilaginis (Pers.) Lév. Diplomarbeit, Universität Tübingen

\section{2}

Deml G, Bauer R, Oberwinkler F (1982a) Axenische Kultur von Coleosporium tussilaginis (Pers.) Lév. (Uredinales). II. Kreuzungsversuche mit monokaryotischen Stämmen. Phytopath Z 103:149-155

Deml G, Bauer R, Oberwinkler F (1982b) Axenic cultures of Coleosporium tussilaginis (Uredinales). I. Isolation, identification and characterization of the cultures. Phytopath. Z. 104:39-45

\section{3}

Bauer R (1983) Experimentell-ontogenetische und karyologische Untersuchungen an Uredinales. Dissertation Universität Tübingen

\section{4}

Oberwinkler F, Bandoni RJ, Bauer R, Deml G, Kisimova-Horovitz L (1984) The life history of Christiansenia pallida, a dimorphic, mycoparasitic heterobasidiomycete. Mycologia 76:9-22

\section{5}

Deml G, Oberwinkler F, Bauer R (1985) Sphacelotheca polygonipersicariae G. Deml \& Oberw. spec. nov. Phytopath Z 113:231-242

\section{6}

Bauer R (1986) Basidiosporenentwicklung und -keimung bei Heterobasidiomyceten. Teil A: Experimentell-ontogenetische und karyologische Untersuchungen an keimenden Rostpilzbasidiosporen. Ber Deutsch Bot Ges 99:67-81

Bauer R, Oberwinkler F (1986a) Experimentell-ontogenetische Untersuchungen an Phragmobasidien. Z Mykol 52:259-264

Bauer R, Oberwinkler F (1986b) Experimentell-ontogenetische und karyologische Untersuchungen an Ochropsora ariae (Fuck.) Ramsb. Z Mykol 52:271-275

\section{7}

Bauer R (1987) Uredinales - Germination of basidiospores and pycnospores. Stud Mycol 30:111-125

\section{8}

Bauer R, Oberwinkler F (1988) Nuclear degeneration during ballistospore formation of Cronartium asclepiadeum (Uredinales). Bot Acta 101:272-282

Laaser G, Jahnke KD, Prillinger HJ, Bauer R, Hoffmann P, Deml G, Oberwinkler F (1988) A new-tremelloid yeast isolated from Asterophora lycoperdoides. Antonie van Leeuwenhoek 54:57-74

\section{9}

Bauer R, Oberwinkler F, Deml G (1989) Ultrastruktur der Basidiensepten phragmobasidialer Brandpilze. Z Mykol 55: 163-168

Nagler A, Bauer R, Berbee ML, Vánky K, Oberwinkler F (1989) Light and electron microscopic studies of Schroeteria delastrina and S. poeltii. Mycologia 81:884-895

Oberwinkler F, Bauer R (1989) The systematics of gasteroid, auricularioid heterobasidiomycetes. Sydowia 41:224-256

1990

Bauer R, Oberwinkler F (1990a) Direct cytoplasm-cytoplasm connection: an unusual host-parasite interaction of the tremelloid mycoparasite Tetragoniomyces uliginosus. Protoplasma 154: $157-160$

Bauer R, Oberwinkler F (1990b) Haustoria of the mycoparasitic heterobasidiomycete Christiansenia pallida. Cytologia 55: 419-424

Bauer R, Oberwinkler F (1990c) Meiosis, spindle pole body cycle and taxonomy of the heterobasidiomycete Pachnocybe ferruginea. Plant Syst Evol 172:241-261

Berbee M, Bauer R, Oberwinkler F (1990) The spindle pole body cycle, meiosis, and basidial cytology of the smut fungus Microbotryum violaceum. Canad J Bot 69:1795-1803 
Nagler A, Bauer R, Oberwinkler F, Tschen J (1990) Basidial development, spindle pole body, septal pore, and host-parasite interaction in Ustilago esculenta. Nord J Bot 10:457-464

Oberwinkler F, Bauer R (1990) Cryptomycocolax: a new mycoparasitic heterobasidiomycete. Mycologia 82:671-692

Oberwinkler F, Bauer R, Bandoni RJ (1990a) Colacogloea: a new genus in the auricularioid heterobasidiomycetes. Canad J Bot 68:25312536

Oberwinkler F, Bauer R, Bandoni RJ (1990b) Heterogastridiales: a new order of Basidiomycetes. Mycologia 82:48-58

Oberwinkler F, Bauer R, Schneller J (1990c) Phragmoxenidium mycophilum sp. nov, an unusual mycoparasitic heterobasidiomycete. System Appl Microbiol 13:186-191

\section{1}

Bauer R, Oberwinkler F (1991) The colacosomes: new structures at the host-parasite interface of a mycoparasitic basidiomycete. Bot Acta 104:53-57

Bauer R, Berbee ML, Oberwinkler F (1991) An electron-microscopic study of meiosis and the spindle pole body cycle in the smut fungus Sphacelotheca polygoni-serrulati. Canad J Bot 69:245-255

\section{2}

Bauer R, Oberwinkler F, McLaughlin DJ (1992) Meiosis, spindle pole body cycle and basidium ontogeny in the heterobasidiomycete Agaricostilbum pulcherrimum. System Appl Microbiol 15:259-274

Vánky K, Bauer R (1992) Conidiosporomyces, a new genus of Ustilaginales. Mycotaxon 43:426-435

\section{3}

Prillinger H, Oberwinkler F, Umile C, Tlachac K, Bauer R, Dörfler C, Taufratzhofer E (1993) Analysis of cell wall carbohydrates (neutral sugars) from ascomycetous and basidiomycetous yeasts with and without derivatization. J Gen Appl Microbiol 39:1-34

\section{4}

Bauer R, Oberwinkler F (1994) Meiosis, septal pore architecture, and systematic position of the heterobasidiomycetous fern parasite Herpobasidium filicinum. Canad J Bot 72:1229-1242

Berndt R, Bauer R, Oberwinkler F (1994) Ultrastructure of the hostparasite interface in the fern rusts Milesia, Uredinopsis, and Hyalopsora (Uredinales, Pucciniastraceae). Canad J Bot 72:10841094

Zugmaier W, Bauer R, Oberwinkler F (1994) Mycoparasitism of some Tremella species. Mycologia 86:49-56

\section{5}

Bauer R, Mendgen K, Oberwinkler F (1995a) Cellular interaction of the smut fungus Ustacystis waldsteiniae. Canad J Bot 73:867-883

Bauer R, Mendgen K, Oberwinkler F (1995b) Septal pore apparatus of the smut Ustacystis waldsteiniae. Mycologia 87:18-24

Kwon-Chung KJ, Chang YC, Bauer R, Swann EC, Taylor JW, Goel R (1995) The characters that differentiate Filobasidiella depauperata from Filobasidiella neoformans. Stud Mycol 38:67-79

Piepenbring M, Bauer R (1995) Noteworthy germinations of some Costa Rican Ustilaginales. Mycol Res 99:853-858

Vánky K, Bauer R (1995) Oberwinkleria, a new genus of Ustilaginales. Mycotaxon 53:361-368

\section{6}

Prillinger H, Messner R, König H, Bauer R, Lopandic K, Molnar O, Dangel P, Weigang F, Kirisits T, Nakase T, Sigler L (1996) Yeasts associated with termites: a phenotypic and genotypic characterization and use of coevolution for dating evolutionary radiations in asco- and basidiomycetes. System Appl Microbiol 19:265-283

Vánky K, Bauer R (1996) Ingoldiomyces, a new genus of Ustilaginales. Mycotaxon 59:277-287

\section{7}

Bauer R, Oberwinkler F (1997) The Ustomycota: an inventory. Mycotaxon 64:303-319
Bauer R, Oberwinkler F, Vánky K, (1997) Ultrastructural markers and systematics in smut fungi and allied taxa. Canad J Bot 75:1273-1314

Begerow D, Bauer R, Oberwinkler F (1997) Phylogenetic studies on nuclear large subunit ribosomal DNA sequences of smut fungi and related taxa. Can J Bot 75:2045-2056

Piepenbring M, Bauer R (1997) Erratomyces, a new genus with species on Leguminosae. Mycologia 89:924-936

Vánky K, Bauer R, Begerow D (1997) Fulvisporium, a new genus of Ustilaginales. Mycotaxon 64:57-66

\section{8}

Bauer R, Begerow D, Oberwinkler F, (1998) Progress in the systematics of smut fungi. Z Pflanzenkrankheiten 105:224-238

Piepenbring M, Bauer R, Oberwinkler F (1998a) Teliospores of smut fungi - general aspects of teliospore walls and sporogenesis. Protoplasma 204:155-169

Piepenbring M, Bauer R, Oberwinkler F (1998b) Teliospores of smut fungi - teliospore walls and the development of ornamentation studied by electron microscopy. Protoplasma 204:170-201

Piepenbring M, Bauer R, Oberwinkler F (1998c) Teliospores of smut fungi - teliospore connections, appendages, and germ pores studied by electron microscopy; phylogenetic discussion of characteristics of teliospores. Protoplasma 204:202-218

Vánky K, Bauer R, Begerow D (1998) Doassinga, a new genus of Doassansiales. Mycologia 90:964-970

1999

Bauer R, Oberwinkler F, Vánky K (1999a) Ustilaginomycetes on Osmunda. Mycologia 91:669-675

Bauer R, Vánky K, Begerow D, Oberwinkler F (1999b) Ustilaginomycetes on Selaginella. Mycologia 91:475-484

Kirschner R, Bauer R, Oberwinkler F (1999) Atractocolax, a new heterobasidiomycetous genus based on a species vectored by conifericolous bark beetles. Mycologia 91:538-543

Oberwinkler F, Bauer R, Tschen J (1999) The mycoparasitism of Platygloea bispora. Kew Bull 51:763-769

Sampaio JP, Bauer R, Begerow D, Oberwinkler F (1999a) Occultifur externus sp. nov, a new species of simple-septate auricularioid heterobasidiomycete from plant litter in Portugal. Mycologia 91: 1094-1101

Sampaio JP, Fell JW, Gadanho M, Bauer R (1999b) Kurtzmanomyces insolitus sp. nov, a new anamorphic heterobasidiomycetous yeast species. System Appl Microbiol 22:619-625

\section{0}

Begerow D, Bauer R, Boekhout T (2000) Phylogenetic placements of ustilaginomycetous anamorphs as deduced from nuclear LSU rDNA sequences. Mycol Res 104:53-60

\section{1}

Bauer R, Begerow D, Oberwinkler F, Piepenbring M, Berbee ML (2001a) Ustilaginomycetes. In Mycota VII Part B. Systematics and evolution. Edited by McLaughlin DJ, McLaughlin EG, Lemke PA, Springer Verlag, Heidelberg, New York, pp. 57-83

Bauer R, Begerow D, Nagler A, Oberwinkler F (2001b) The Georgefischeriales: a phylogenetic hypothesis. Mycol Res 105: 416-424

Begerow D, Bauer R, Oberwinkler F (2001) Muribasidiospora: Microstromatales or Exobasidiales? Mycol Res 105:798-810

Kirschner R, Bauer R, Oberwinkler F (2001) Colacosiphon: a new genus described for a mycoparasitic fungus. Mycologia 93:634-644

Sampaio JP, Gadanho M, Bauer R (2001) Taxonomic studies on the genus Cystofilobasidium: description of Cystofilobasidium ferigula sp. nov. and clarification of the status of Cystofilobasidium larimarini. Int J System Evol Microbio 51:221-229

\section{2}

Begerow D, Bauer R, Oberwinkler F (2002a) The Exobasidiales: an evolutionary hypothesis. Mycol Progr 1:187-199 
Begerow D, Bauer R, Oberwinkler F (2002b) The sterigmata of Volvocisporium: a clarification. Mycol Res 106:131

Sampaio JP, Weiß M, Gadanho M, Bauer R (2002) New taxa in the Tremellales: Bulleribasidium oberjochense gen. et sp. nov, Papiliotrema bandonii gen. et sp. nov. and Fibulobasidium murrhardtense sp. nov. Mycologia 94:873-887

Selosse MA, Bauer R, Moyersoen B (2002) Basal hymenomycetes belonging to the Sebacinaceae are ectomycorrhizal on temperate deciduous trees. New Phyt 155:183-195

\section{3}

Bauer R, Begerow D, Oberwinkler F, Marvanova L (2003) Classicula: the teleomorph of Naiadella fluitans. Mycologia 95:756-764.

Hendrichs M, Bauer R, Oberwinkler F (2003) The Cryptobasidiaceae of tropical Central and South America. Sydowia 55:33-64

Prillinger H, Lopandic K, Schweigkofler W, Deak R, Aarts HJ, Bauer R, Sterflinger K, Kraus GF, Maraz A (2002) Phylogeny and systematics of the fungi with special reference to the Ascomycota and Basidiomycota. In: Breitenbach M, Crameri R, Lehrer SB (eds.). Fungal Allergy and Pathogenicity. Chem Immunol 81:207-295

Sampaio JP, Gadanho M, Bauer R, Weiß M (2003) Taxonomic studies in the Microbotryomycetidae: Leucosporidium golubevii sp. nov., Leucosporidiella gen. nov. and the new orders Leucosporidiales and Sporidiobolales. Mycol Progr 2:53-68

Urban A, Weiß M, Bauer R (2003) Ectomycorrhizae in the Sebacinaceae. Mycol Res 107:3-14

\section{4}

Bauer R (2004) Basidiomycetous interfungal cellular interactions - a synopsis. In: Agerer R, Piepenbring M, Blanz P, (eds) Frontiers in basidiomycote mycology. IHW-Verlag, Eching, pp. 325-337

Bauer R, Oberwinkler F (2004) Cellular ustilaginomycete-host interactions. In: Varma A, Abbott L, Werner D, Hampp R (eds). Plant Surface Microbiology. Springer, Heidelberg, pp 227-236

Bauer R, Lutz M, Oberwinkler F (2004) Tuberculina-rusts: a unique basidiomycetous interfungal cellular interaction with horizontal nuclear transfer. Mycologia 96:960-967

Hendrichs M, Oberwinkler F, Begerow D, Bauer R (2004) Carex, subgenus Carex (Cyperaceae) - A phylogenetic approach using ITS sequences. Plant Syst Evol 246:89-107

Lutz M, Bauer R, Begerow D, Oberwinkler F, Triebel D (2004a) Tuberculina: rust relatives attack rusts. Mycologia 96:614-626

Lutz M, Bauer R, Begerow D, Oberwinkler F (2004b) TuberculinaThanatophytum / Rhizoctonia crocorum - Helicobasidium: a unique mycoparasitic-phytoparasitic life strategy. Mycol Res 108: 227-238

Lutz M, Bauer R, Begerow D, Oberwinkler F (2004c) TuberculinaHelicobasidium: host specificity of the Tuberculina-stage reveals unexpected diversity within the group. Mycologia 96:1316-1329

Simon UK, Bauer R, Oberwinkler F (2004) The unique cellular interaction between the leaf pathogen Cymadothea trifolii and Trifolium repens. Mycologia 96:1209-1217

Weiß M, Bauer R, Begerow D (2004) Spotlights on heterobasidiomycetes. In Agerer R, Piepenbring M, Blanz $\mathrm{P}$ (eds) Frontiers in Basidiomycote Mycology, pp. 7-48. IHW-Verlag, Eching

\section{5}

Bauer R, Lutz M, Oberwinkler F (2005) Gjaerumia, a new genus in the Georgefischeriales (Ustilaginomycetes). Mycol Res 109:1250-1258

Hendrichs M, Begerow D, Bauer R, Oberwinkler F (2005) The genus Anthracoidea (Basidiomycota, Ustilaginales) a molecular phylogenetic approach using LSU rDNA sequences. Mycol Res 109:31-40

Simon UK, Bauer R, Rioux D, Simard M, Oberwinkler F (2005a) The intercellular biotrophic leaf pathogen Cymadothea trifolii locally degrades pectins, but not cellulose or xyloglucan in cell walls of Trifolium repens. New Phyt 165:243-260

Simon UK, Bauer R, Rioux D, Simard M, Oberwinkler F (2005b) The vegetative life-cycle of the clover pathogen Cymadothea trifolii as revealed by transmission electron microscopy. Mycol Res 109:764-778

\section{6}

Aime MC, Matheny PB, Henk DA, Frieders EM, Nilsson RH, Piepenbring M, Mclaughlin DJ, Szabo LJ, Begerow D, Sampaio JP, Bauer R, Weiß M, Oberwinkler F, Hibbett D (2006) An overview of the higher level classification of Pucciniomycotina based on combined analyses of nuclear large and small subunit rDNA sequences. Mycologia 98:896-905

Bauer R, Begerow D, Sampaio JP, Weiß M, Oberwinkler F (2006) The simple-septate basidiomycetes: a synopsis. Mycol Progr 5:41-66

Begerow D, Stoll M, Bauer R (2006) A phylogenetic hypothesis of Ustilaginomycotina based on multiple gene analyses and morphological data. Mycologia 98:906-916

Celio GJ, Padamsee M, Dentinger BTM, Bauer R, McLaughlin DJ (2006) Assembling the Fungal Tree of Life: constructing the structural and biochemical database. Mycologia 98:850-859

De Beer W, Begerow D, Bauer R, Pegg GS, Crous PW, Wingfield MJ (2006) Phylogeny of the Quambalariaceae fam. nov, including important Eucalyptus pathogens in South Africa and Australia. Stud Mycol 55:293-302

Lutz M, Bauer R, Oberwinkler F (2006) Das Doppelleben des Birnengitterrostes. Forschung 4/2006:13-15

Oberwinkler F, Kirschner R, Arenal F, Villareal M, Rubio V, Begerow D, Bauer R (2006) Two new pycnidial members of the Atractiellales: Basidiopycnis hyalina and Proceropycnis pinicola. Mycologia 98: 637-649

\section{7}

Bauer R, Lutz M, Piatek M, Vánky K, Oberwinkler, F (2007) Flamingomyces and Parvulago, new genera of marine smut fungi (Ustilaginomycotina). Mycol Res 111:1199-1206

Hibbett DS, Binder M, Bischoff JF, Blackwell M, Cannon PF, Eriksson OE, Huhndorff S, James T, Kirk PM, Lücking R, Lumbsch HL, Lutzoni F, Matheny PB, McLaughlin DJ, Powell MJ, Redhead S, Schoch CL, Spatafora JW, Stalpers JA, Vilgalys R, Aime MC, Aptroot A, Bauer R, Begerow D, Benny GL, Castlebury LA, Crous PW, Dai Y-C, Gams W, Geiser DM, Griffith GW, Gueidan C, Hawksworth DL, Hestmark G, Hosaka K, Humber RA, Hyde KD, Ironside JE, Kõljalg U, Kurtzman CP, Larsson K-H, Lichtwardt R, Longcore J, Miadlikowska J, Miller A, Moncalvo J-M, MozleyStandridge S, Oberwinkler F, Parmasto E, Reeb V, Rogers JD, Roux C, Ryvarden L, Sampaio JP, Schüßler A, Sugiyama J, Thorn RG, Tibell L, Untereiner WA, Walker C, Wang Z, Weir A, Weiß M, White MM, Winka K, Yao Y-J, Zhang N (2007) A higher-level phylogenetic classification of the Fungi. Mycol Res 111:509-547

Lutz M, Bauer R, Oberwinkler F (2007) The double life of a fungus. German Research 1/2007:21-23

Vánky K, Bauer R, Begerow D (2007) Talbotiomyces, a new genus for Entorrhiza calospora (Basidiomycota). Mycol Balcan:4:11-14

\section{8}

Bauer R, Lutz M, Begerow D, Piatek M, Vánky K, Bácigalová K, Oberwinkler F (2008) Anther smut fungi on monocots. Mycol Res 112:1297-1306

Scheuer C, Bauer R, Lutz M, Stabentheiner E, Mel'nik VA, Grube M (2008) Bartheletia paradoxa is a living fossil on Ginkgo leaf litter with a unique septal structure in the Basidiomycota. Mycol Res 112: $1265-1279$

Vánky K, Lutz M, Bauer R (2008a) About the genus Thecaphora (Glomosporiaceae) and its new synonyms. Mycol Progr 7:31-39

Vánky K, Lutz M, Bauer R (2008b) Floromyces, a new genus of Ustilaginomycotina. Mycotaxon 104:171-184

\section{9}

Bauer R, Metzler B, Begerow D, Oberwinkler F (2009) Cystobasidiopsis nirenbergiae, a new agaricostilbomycete (Pucciniomycotina). Mycol Res 113:960-966

Prillinger H, Wuczkowski M, Lopandic K, Bauer R, Molmár O, Sterflinger K (2009) Schizonella caricis-atratae 
(Ustilaginomycetes) a new cryptic species on Carex atrata from Austria. Mycol Progr 8:157-164

Simon UK, Groenewald JZ, Stierhof Y-D, Crous PW, Bauer R (2009) Mycosphaerella podagrariae - a necrotrophic phytopathogen forming a special cellular interaction with its host Aegopodium podagraria. Mycol Progr 9:49-56

\section{0}

Kottke I, Suárez JP, Herrera P, Cruz D, Bauer R, Haug I, Garnica S (2010) Atractiellomycetes belonging to the 'rust' lineage (Pucciniomycota) form mycorrhizae with terrestrial and epiphytic neotropical orchids. Proc Royal Soc B 277:1289-1298

Schäfer AM, Kemler M, Bauer R, Begerow D (2010) The illustrated life cycle of Microbotryum on the host plant Silene latifolia. Canad J Bot $88: 875-885$

\section{1}

Lutz M, Vánky K, Bauer R (2011) Melanoxa, a new genus in the Urocystidales. Mycol Progr 11:149-158

Krause C, Garnica S, Bauer R, Nebel M (2011) Aneuraceae (Metzgeriales) and tulasnelloid fungi (Basidiomycota) - a model for early steps in fungal symbiosis. Fungal Biology115:839-851

Weiß M, Sykorová Z, Garnica S, Riess K, Martos F, Krause C, Oberwinkler F, Bauer R, Redecker D (2011) Sebacinales everywhere: previously overlooked ubiquitous fungal endophytes. PloS ONE 6(2) e16793

\section{2}

Garnica S, Riess K, Bauer R, Oberwinkler F, Weiß M (2012) Phylogenetic diversity and structure of sebacinoid fungi associated with plant communities along an altitudinal gradient. FEMS Microbiol Ecol, DOI: 10.1111/j.1574-6941.2012.01473.x

\section{3}

Oberwinkler F, Riess K, Bauer R, Selosse M-A, Weiß M, Garnica S, Zuccaro A (2013a) Enigmatic Sebacinales. Mycol Progr, DOI 10.1007/s11557-012-0880-4

Oberwinkler F, Riess K, Bauer R, Kirschner R, Garnica S (2013b) Taxonomic re-evaluation of the Ceratobasidium-Rhizoctonia complex and Rhizoctonia butinii, a new species attacking spruce. Mycol Progr, DOI 10.1007/s11557-013-0936-0

Riess K, Oberwinkler F, Bauer R, Garnica S (2013) High genetic diversity at the regional scale and possible speciation in Sebacina epigaea and S. incrustans. BMC Evol Biol 13:102, http:// www.biomedcentral.com/1471-2148/13/102

\section{4}

Begerow D, Schäfer AM, Keller R, Yurkov A, Kemler M, Oberwinkler F, Bauer R (2014) Ustilaginomycetes. In: Mycota VII Part A. Systematics and evolution. Edited by McLaughlin DJ, Spatafora JW. Springer, pp. 295-329

Hibbett DS, Bauer R, Binder M, Giachini AJ, Hosaka K, Justo A, Larsson E, Larsson KH, Lawrey JD, Miettinen O, Nagy LG, Nilsson RH, Weiss M, Thorn RG (2014) Agaricomycetes. In: Mycota VII Part A. Systematics and evolution. Edited by McLaughlin DJ, Spatafora JW. Springer, pp. 372-429

Oberwinkler F, Riess K, Bauer R, Garnica S (2014) Morphology and molecules: the Sebacinales, a case study. Mycol Progr, DOI 10.1007/s11557-014-0983-1

Riess K, Oberwinkler F, Bauer R, Garnica S (2014) Communities of endophytic Sebacinales associated with roots of herbaceous plants in agricultural and grassland ecosystems are dominated by Serendipita herbamans sp. nov. PloS ONE 9(4): e94676. doi: 10.1371/journal.pone.0094676

Rodríguez Justavino D, Carranza Velásquez J, Morales Sánchez CO, Rincón R, Oberwinkler F, Bauer R (2014) The interaction apparatus of Asteridiella callista (Meliolaceae, Ascomycota) Mycologia 106: 216-223

Weiß M, Bauer R, Sampaio JP, Oberwinkler F (2014) Tremellomycetes and related groups. In: Mycota VII Part A. Systematics and evolution. Edited by McLaughlin DJ, Spatafora JW. Springer, pp. 331-355

Wood AR, Lutz M, Bauer R, Oberwinkler F (2014) Morphology and phylogenetics of Stomatisora, including Stomatisora psychotriicola sp. nov. Mycol Progr, DOI 10.1007/s11557-014-0997-8

\section{5}

Bauer R, Garnica S, Oberwinkler F, Riess K, Weiß M, Begerow D (2015) Entorrhizomycota: a new fungal phylum reveals new perspectives on the evolution of fungi. PLoS ONE 10(7): e0128183. doi:10.1371/ journal.pone. 0128183

Riess K, Bauer R, Kellner R, Kemler M, Piątek M, Vánky M, Begerow D (2015) Identification of a new order of root-colonising fungi in the Entorrhizomycota: Talbotiomycetales ord. nov. on eudicotyledons. IMA Fungus 6:129-133

Sharma R, Gassel S, Steiger S, Xia X, Bauer R, Sandmann G, Thines M (2015) The genome of the basal agaricomycete Xanthophyllomyces dendrorhous provides insights into the organization of its acetylCoA derived pathways and the evolution of Agaricomycotina. BMC Genomics 16:233, DOI 10.1186/s12864-015-1380-0 